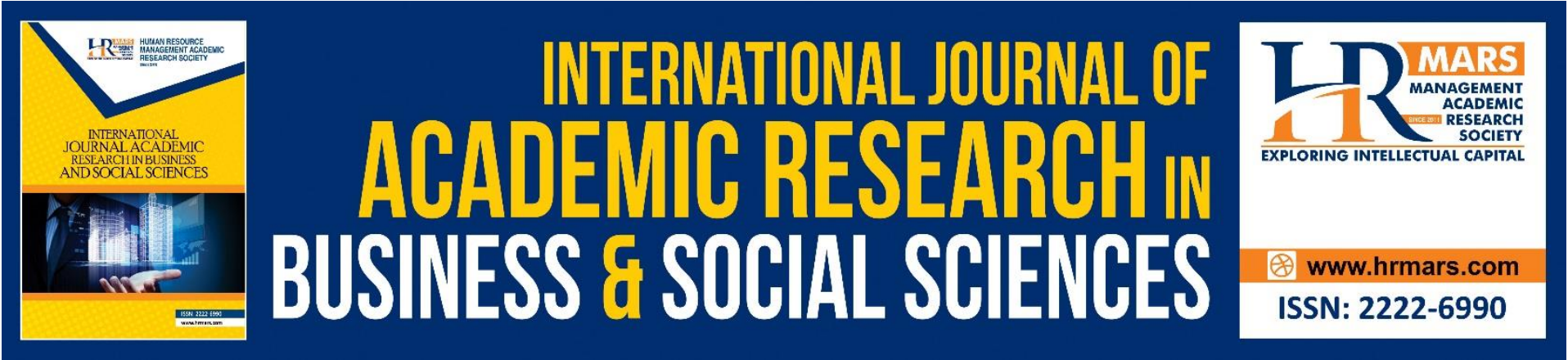

\title{
The Characteristics of Household Loans in Conventional and Islamic Banks in Malaysia
}

Nora Azureen Abdul Rahman, Zunarni Kosim, Siew Goh Yeok

To Link this Article: http://dx.doi.org/10.6007/IJARBSS/v8-i7/4395

DOI: $\quad 10.6007 /$ IJARBSS/v8-i7/4395

Received: 27 May 2018, Revised: 16 June 2018, Accepted: 29 June 2018

Published Online: 14 July 2018

In-Text Citation: (Rahman, Kosim, \& Yeok, 2018)

To Cite this Article: Rahman, N. A. A., Kosim, Z., \& Yeok, S. G. (2018). The Characteristics of Household Loans in Conventional and Islamic Banks in Malaysia. International Journal of Academic Research in Business and Social Sciences, 8(7), 531-541.

Copyright: (C) 2018 The Author(s)

Published by Human Resource Management Academic Research Society (www.hrmars.com)

This article is published under the Creative Commons Attribution (CC BY 4.0) license. Anyone may reproduce, distribute, translate and create derivative works of this article (for both commercial and non-commercial purposes), subject to full attribution to the original publication and authors. The full terms of this license may be seen at: http://creativecommons.org/licences/by/4.0/legalcode

Vol. 8, No. 7, July 2018, Pg. 531 - 541

http://hrmars.com/index.php/pages/detail/IJARBSS

JOURNAL HOMEPAGE

Full Terms \& Conditions of access and use can be found at http://hrmars.com/index.php/pages/detail/publication-ethics 


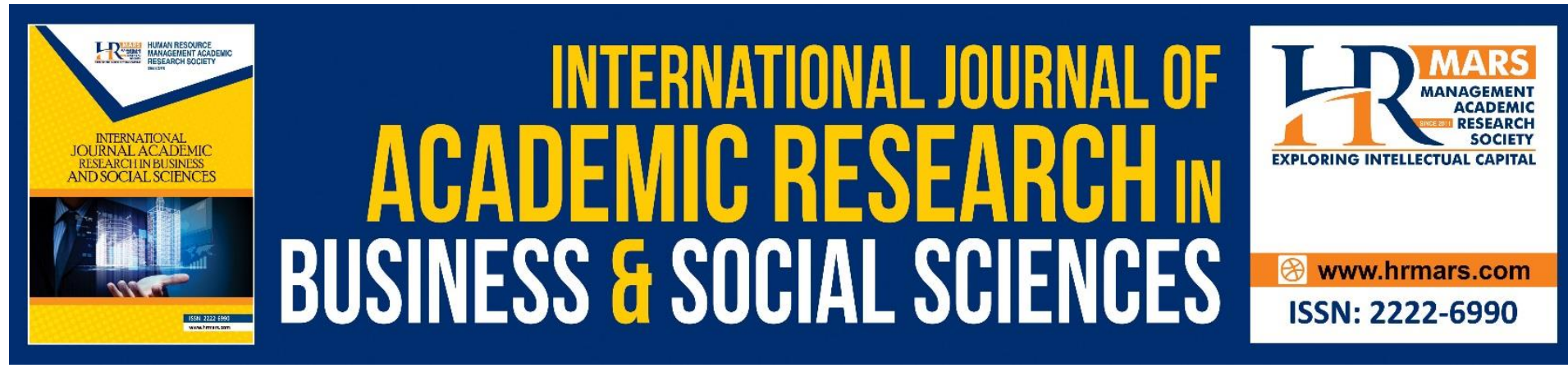

\title{
The Characteristics of Household Loans in Conventional and Islamic Banks in Malaysia
}

\author{
Nora Azureen Abdul Rahman, Zunarni Kosim, Siew Goh \\ Yeok \\ Universiti Utara Malaysia, Malaysia
}

\begin{abstract}
The high debts among Malaysia's households and the dual banking system in Malaysia motivates this study to investigate the characteristics of the household loan in the conventional and Islamic banking institutions. The loan characteristics are vital as it serves as 'red flags' of loan default in the banking institutions. As conventional banks and Islamic banks are under different banking concepts and principles; normally accompanied by different loan policy and strategies, this study provides insights on the loan characteristics of the banking institutions. Using the estimated logit model, the results give information on the exposure to risk of default of the banking institutions. The results may be useful in the formulation of the lending policies of the banking institutions.
\end{abstract}

Keywords: Households. Loan. Conventional banks. Islamic banks. Malaysia

\section{Introduction}

High debts among Malaysia's households is not a new issue. It has long been debated among economists, researchers and the policy makers and several suggestions have been highlighted to curb the issue. However, despite reforms and macroeconomic measures implemented, the household debts keep rising from year to year. Malaysia's household debts to gross domestic products (GDP) has been above $60 \%$ since early 2000 s, and has been on the uptrend since then. In 2013, the Malaysia's household debts to GDP is $86.8 \%$, which is one of the highest in the Asia Pacific Region (Alias, Huat \& Mohamad, 2014). As of 2015 , the household debt to GDP is $89.1 \%$, which is the highest as compared to Indonesia (16.8\%), Philippines (35\%), Thailand (84\%), Hong Kong (67.1\%), Singapore (72\%), South Korea (88.4\%) and China (39.5\%) (MIDF, 2016). The Edge (2010) reports that the ratio of household debts to disposable income is $\mathbf{1 4 0 . 4}$ percent; indicating that on average, the loan taken by each household in Malaysia is 1.4 times more than their incomes; the ratio is above Singapore, USA, Korea, Thailand and Indonesia. In fact, the ratio has made Malaysia's household debt among the highest in the world.

The Malaysia's households are stretched on debt servicing, even beyond the USA and Korea (Standard Chartered Report, 2016). Malaysia's household debts are approaching levels that could force them to de-leverage at a time when the economy is in dire need of domestic consumer support (The Malay Mail, 2016). 
In Malaysia, the banking institutions act as the main financier to the households. The tendency to provide loans to the households implies that household loans are a profitable business for the banking institutions. Loan to the households is mounting since the year 2000 and in 2004, it has surpassed the banking institutions' business loan activities (Bank Negara Malaysia, 2005). Loan to individuals increases from 34 percent to 56 percent between 2000 to 2010; higher than loan to the corporate sectors (Hui, 2011). Loan to the household sector as at 2012 stands at RM616 billion against the banks' total financing outstanding of RM1,108 billion (Bank Negara Malaysia, 2013); indicating that household loans are the major business of the banking institutions. The household loans are offered through two types of banking institutions; the conventional banks and the Islamic banks. The Islamic banks, which operating side-by-side with the conventional banks, offer similar competitive types of household loans as the conventional banks (i.e., housing loan, hirepurchase loan, credit card loan and personal loan). However, unlike the conventional banks, all the loan products are based on Syariah concepts. The Islamic banking products are increasingly becoming the choice of many customers in Malaysia (Hamed et al., 2011).

The dual banking system in Malaysia creates a competitive environment among the banking institutions. While the banking institutions scramble to attract customers in order to achieve their expected profits, the customers have more choices of banking products that suit them; especially when Malaysia is having a multiracial society and religions. Hence, given the escalating trend of household debts in Malaysia and the dual structure of the banking system, this study attempt to investigate the characteristics of household loans in the Malaysia's banking institutions. The study tries to answer questions such as; which banks are more preferred by the borrowers?, which banks have borrowers with a more stable financial standing?, which banks have a more risky borrowers? The results are vital as it will serve as 'red flags' or indicator for loan defaults. The 'red flags' provide early symptoms that the borrowers might be having financial problem and have difficulties to service their debts. It is critical to get into the identification process early; the remedialaction window is finite and waiting too long will result in banks losing options and so does the borrower (McLaughlin, 2009).

\section{Literature Review}

Household debt can be in the form of short term loan (i.e.,consumer loan) and long term loan (i.e.,mortgage loan). Beer and Schurz (2007) indicate that hire purchase loan, credit card loan, personal loan and housing loan are the type of loans that normally associated with households. In Malaysia, the bulk of Malaysia's household debts is in housing loans, follows by hire-purchase loans and credit card loans (Endut \& Hua, 2009). Nakornthab (2010) indicates that mortgage loan constitutes the largest portion of Malayia's household debts, follows by hire-purchase loan, credit card loan and personal loan. Yusof, Rokis and Jusoh (2015) claim that Malay and Indian ethnic are vulnerable to financial shocks due to high household debts.

The borrowers' loan characteristics are essential 'red flags' of loan defaults. The inability to fulfil the required loan characteristics such as pay back loan within the time frame given, pay deposits and low debt service ratio (DSR) indicates a high possibility of defaults. Sorenson (2015) claims that loan characteristics influence foreclosure. Antwi et $a l, 2012$ ) relates loans which are not paid within the repayment period as defaulted. A loan 
default occurs when borrowers do not make required payments as in the loan contract (Korankye, 2014). Zablon, Sambiri and Otieno (2015) note that default happens when debtors fail to pay his debts on time, while Korankye (2014) indicates that late loan repayment problem will increase the credit risk of banks.

Jimenez and Saurina (2015) claim that the larger the amount of loans, the lower is the credit risk. This is due to the more rigorous and careful screening process that the loan has to undergo. However, Durkin and Elliehausen (2015) argues that large scale of loan increases the likelihood of default. Borrowers with low creditworthiness will be given a low amount of loan, as they have high potential of not paying back the loan (Singh, 2012). Sharing the view, Berger and Molyneux (2015) argue that greater loan amounts entail greater default risk. A larger loan size indicates greater financial risk, which would contribute to greater risk of default (Dodson \& Koenig, 2008)..

Deposit paid refers to the upfront portion of the total loan amount; usually given in cash at the time of finalizing the transaction. Frais (2017) notes that deposits paid by borrowers lowering the credit risk faced by lenders; the more the borrower pays the deposits, the less likely he or she is to default on the loan. The deposits paid indicates the financial ability of the borrower. Fewer financial resources, the borrower are expected to be more likely to default (Dodson \& Koenig, 2008). Deposits paid or a down payment gives a strong indication of the borrower's ability to pay the loan each month (Bui, 2015).

Johnson and $\mathrm{Li}$ (2010) indicate that DSR is a useful measure of household borrowing constraints. DSR is one of the indicators of household financial health; used to gauge the burden of debt servicing for households (Faruqui, 2008)]. DSR is one of the most important indicators that can provide greater insights into the assessment of financial distress and debt repayment capacity of households across different income groups (Rani et al., 2017). The DSR would ensure that borrowers will have sufficient financial buffers to protect them against delinquency due to unexpected events such as bankruptcy. In Malaysia, DSR is used by every commercial bank in analysing the borrowers' financial condition, which is, the ability of the borrower to service his/her loan instalment. Lower DSR percentage signifies a strong financial condition.

\section{Methodology}

This study employs a quantitative research approach, in which primary data are collected using questionnaires. The questionnaire is developed based on measures used in previous related studies to gain information on the indebtedness of households. This study focuses only on households located at three northern states of Malaysia, namely, Perlis, Kedah and Penang; with a total population of 4 million people as of 2015 (The Statistic Department, 2016).

Consistent with the sampling rules suggested by (Krejcie \& Morgan, 1970), this study distributes a total of 600 questionnaires to the households in Kubang Pasu, North Seberang Perai and Perlis: the largest district in the three states and have the highest number of population. Krejcie and Morgan (1970) indicate that the sample size for a population of more than 75,000 is 382 ; hence, 600 respondents as sample for this study is considered enough to represent the whole population of the three focus areas. The questionnaires are distributed using a convenience sampling method. This is due to its advantages such as easily accessible, and requires little effort and time (Zikmund \& Babin, 2007). A 
convenience sampling is appropriate when "the researcher selects participants because they are willing and available to be studied". Nevertheless, of the 600 questionnaires, only 289 can be analysed. This is due to inadequate information provided by the respondents. Out of the 289 questionnaires analysed, 245 of the respondents have loans in the banking institutions while the remainder have loans in the non-banking institutions. Thus, only 245 respondents / questionnaires are analysed as the objective of the study is to investigate the loan characteristics of borrowers who have loans in the banking institutions, i.e., conventional banks and Islamic banks.

In this study, the term debt refers to loans taken by households. The loans were differentiated into housing loan, hire purchase loan, credit card loan and personal loan; the type of loans that normally associated with household debt (Beer \& Schurz, 2007). The definition of each type of loans is according to the definition used by Malaysia's financial institutions. This is an attempt to create consistency between survey-based indicators with the loan definitions given in the financial accounts and, to facilitate the households in understanding and answering the questions in the questionnaire.

Housing loan refers to loan earmark for the purchase or construct a house or building; hire purchase loans are loan taken to buy private vehicle; credit card loan refer to users who continue to carry a balance on their credit cards after the grace period (the number of days between a customer's credit card statement date and payment due date when interest does not accrue) has expired and the debt begins to bear interest while, personal loan is an unsecured loan taken by household for personal use such as buying a television, refrigerator, computer, vacation, medical, education, etc.

Four loan characteristics such as repayment trend, loan amount, deposit paid and DSR are tested. Although DSR is not a loan characteristics per se, it carries a similar risk to the banking institution, which is, the risk of default. A high DSR indicates high loan commitments; hence, lower ability to service debts as a large portion of the income is used to pay debts. DSR is the first measure done by the financial institutions in their loan screening process. However, the DSR in this study refers to the post- loan DSR; meaning, the DSR calculated in this study is after the borrowers have acquired and service the loans for quite some time. The rationale for the post-loan DSR is that all the respondents of the study have some types of loans in the banking institutions; indicating that they have fulfilled the pre-loan DSR required by the banking institutions to enable them to obtain the loans. Next, the post-loan DSR is important as failure to uphold a certain level of DSR shows that the borrower is having more financial commitments, which might lead to financial difficulties and thus might affects the ability to pay back the loan.

In this study, the repayment trend is divided into four categories (i.e., repayment made in less than 1 month, 2-3 months, 3-4 months, more than 4 months), where the lowest categories indicate that the borrowers pay their debts on time or within the time frame given, and the highest categories indicate poor repayment trends or inability to service debts. The post-loan DSR is divided into three categories; less than 40 percent, between 40-60 percent, and more than 60 percent. The DSR is calculated by dividing debts to income where the lower level DSR implies a better ability to service debts.

In analysing the data, this study employs an estimated logit model. Assume that there is a latent variable which relate to the choice of types of loan/bank institution/Islamic loan, as follows: 


$$
y_{i}^{*}=\sum_{i=1}^{n} \beta x_{i}+u_{i}
$$

Where

$y^{*}=$ the unobserved individual's choice on types of loan/bank institute/Islamic loan

$X=$ the independent variables, including loan characteristics

The observed choice $(y)$ is in dichotomous category such that:

If $y_{i}=1$ (choose "housing/hire-purchase/credit card/personal loan"/bank institution/Islamic) if $y_{i}^{*}>0$

If $y_{i}=0 \quad$ (choose otherwise) if $y_{i}^{*} \leq 0$

Assume that the error term $(u)$ is logistically distributed, the probability that a borrower chooses the "housing/hire-purchase/credit card/personal loan"/bank institution/Islamic loan could be estimated as below:

$$
\begin{aligned}
\operatorname{Prob}(y=1 \mid x) & =\operatorname{Prob}\left(y^{*}>0\right)=\operatorname{Prob}\left(\beta^{\prime} x+u>0\right)=\operatorname{Prob}\left(u>-\beta^{\prime} x\right) \\
& =\operatorname{Prob}\left(u<\beta^{\prime} x\right)=f\left(\beta^{\prime} x\right)
\end{aligned}
$$

The model can be estimated using the maximum likelihood methods with the robust variance estimates (Huber/White/sandwich estimator of variance).

\section{Results and Discussions}

Table 1 shows that the majority of the respondents in the study chooses conventional banks than the Islamic banks. Although 89 percent of the respondents are Malay, which normally associated with Islam as their religion, most of them prefer to have loan with conventional banks than the Islamic banks. This could be due to the trust that have been established between the respondents and the banks as the conventional banks have been operating in Malaysia's market for a very long time and have built a good reputation. Reputation is one of the top ten parameters in bank selection decisions (Kamakodi \& Khan, 2008). Having a good reputation helps to resolve the problem of information asymmetries, especially important when a financial transaction has long-term implications (Vanston, 2012). Kamarulzaman and Madun (2013) mention that although the first Islamic bank has been in existence for more than 27 years, its presence in the market either not really seen or significant. Further, Haron and Wan Azmi (2005) indicate that Islamic banks in Malaysia do not market their product aggressively. Hence, lack of awareness, less information and knowledge of the Islamic banking products and services, due to poor promotions and publicity, could be another plausible reason why the respondents choose conventional banks than the Islamic banks. Marketing method is important as it define a bank and separate it from other banks (Mahtab \& Abdullah, 2016). 
Table 1 Households Debts: Conventional and Islamic banks

\begin{tabular}{lcc}
\multicolumn{1}{c}{ Type } & $\begin{array}{c}\text { Frequen } \\
\text { cy }\end{array}$ & $\begin{array}{c}\text { Percenta } \\
\text { ge (\%) }\end{array}$ \\
\hline $\begin{array}{l}\text { Conventional } \\
\text { Banks } \\
\text { Islamic Banks }\end{array}$ & 143 & 58.4 \\
\hline
\end{tabular}

$N=245$

As for the estimated logit model, Table 2 shows that overall fit tests for the model is found to be significant, with $\mathrm{p}$-values of almost equal to zero. The Pseudo $\mathrm{R}^{2}$ ranges from 0.5039 to 0.8662 ; indicating that the estimated models are fit into the sample.

In terms of repayment trend, Table 2 shows that it is significant to housing loan and credit card loan, with low values; indicating that borrowers with good repayment trend are less likely to have housing loan and credit card loan with the Islamic banks. The good repayment trend of the borrowers suggesting a high commitment of the borrowers towards their debts and high financial capability. Repayment trend reflects the reputation of the borrower (Feschijan, 2008). The author argues that borrower's reputation is of great importance when taking a decision for extending a credit. Paying back loans within the time period implies the character of the borrower. Character is the most important element in the 5Cs evaluation process (Nirmala, 2008). Good payment trend will increase the possibility of getting new loans while, a bad repayment trend will hurt the borrowers' credit scores, reputation and chances of getting loans in the future.

As for the loan amount, it is found that there is a significant and positive influence on the likelihood of using Islamic banks than the conventional banks. The results show that the higher the loan amount, the more likely the borrowers will choose Islamic loans (i.e., housing, hire-purchase, credit card or personal loan); suggesting that the Islamic banks have more risky borrowers than the conventional banks (Durkin \& Elliehausen, 2015; Berger \& Molyneux, 2015; Singh, 2012; Dodson \& Koenig, 2008).

In terms of deposit paid, it is found that it has insignificant differences in the choice of Islamic loan. As DSR is concerned, it is found that the post-loan DSR is only significant to credit card loans, with low value; implying that borrowers with lower DSR are more likely to choose to have credit card loans with the Islamic bank than the conventional bank. The finding suggests that the Islamic banks are more likely to have high financial capability borrowers of credit card loan compared to the conventional banks. The low post-loan DSR would ensure that borrowers will have sufficient financial buffers to protect them against delinquency due to unexpected events such as bankruptcy.

As for the demographic factors, Table 2 demonstrates that male borrowers tend to have housing loans in the Islamic banks rather than the conventional banks. Further, the table shows that compared to other races, Malay borrowers tend to have loans with Islamic banks for housing, hire-purchase and credit card loans. The majority of borrowers with a degree qualification choose to have hire-purchase loans in the Islamic banks while, a higher education level (i.e., postgraduate such as master and $\mathrm{PhD}$ ) is found to have insignificant differences in the choice of Islamic loan. Similarly, factors such as personal status (i.e., single, married, divorced) and employment (i.e., employed or not employed) are found to have insignificant differences in the choice of Islamic loan. Nevertheless, borrowers who 
are under Employees Provident Funds (EPF) scheme, a scheme which provides retirement benefits to its members through management of their savings and other pension schemes, tend to have hire-purchase loans and credit card loans in Islamic banks than the conventional banks. As age is concerned, the results show that younger borrowers tend to choose Islamic banks as compared to the conventional banks.

\section{Conclusion}

Overall, the results indicate a different household loan characteristics of Islamic banks and conventional banks in Malaysia. Understanding the loan characteristics is vital as it provides early symptoms of loan default. The results indicate that borrowers with higher financial capability and good repayment attitude prefer the conventional banks than the Islamic banks; thus, reduce the risk of default of the conventional banks. On the other hand, borrowers with large loan amount prefer to have loans in the Islamic banks in which, will expose the banks to higher risk of default. However, the post-loan DSR shows that borrowers with lower DSR choose to have credit card loan with the Islamic banks. Based on the results, it can be concluded that Islamic banks are likely to expose to higher risk of default than the conventional banks. However, the results are only based on the borrowers in three states. As Malaysia consists of several states, a thorough study which includes all the states in Malaysia is needed in order to come out with a more robust result. The study is vital as it may provide insights to the banking institutions which may be useful in formulating the banks lending policy.

Table 2. The estimated logit models for Islamic or conventional loan

\begin{tabular}{|c|c|c|c|c|c|c|c|c|}
\hline \multirow[t]{2}{*}{$\begin{array}{l}\text { Islamic or } \\
\text { conventional } \\
\text { bank }\end{array}$} & \multicolumn{2}{|c|}{ Housing loan } & \multicolumn{2}{|c|}{ Hire-purchase loan } & \multicolumn{2}{|c|}{ Credit card loan } & \multicolumn{2}{|c|}{ Personal loan } \\
\hline & Coeff. & $\begin{array}{l}\mathrm{P} \text { - } \\
\text { value }\end{array}$ & Coeff. & P-value & Coeff. & $\begin{array}{l}\text { P- } \\
\text { value }\end{array}$ & Coeff. & $\begin{array}{l}\mathrm{P}- \\
\text { value }\end{array}$ \\
\hline Repayment & $0.6463 * * *$ & 0.0360 & 0.4876 & 0.1470 & $0.7917^{*}$ & 0.0510 & -0.1066 & 0.7740 \\
\hline Loan amount & $0.0000 * * *$ & 0.0050 & $0.0001 * * *$ & 0.0000 & $0.0001 *$ & 0.0820 & $0.0000 * * *$ & 0.0030 \\
\hline Deposit paid & 0.0000 & 0.6560 & -0.0001 & 0.1520 & n.a. & n.a. & n.a. & n.a. \\
\hline DSR & 0.0571 & 0.2600 & -0.0010 & 0.9890 & $-0.7969 * * *$ & 0.0000 & 0.0251 & 0.6700 \\
\hline Dmale & $0.9828 * *$ & 0.0370 & 0.5878 & 0.2970 & 0.3164 & 0.6660 & -0.3159 & 0.5230 \\
\hline DMalay & $2.8866 * *$ & 0.0260 & $5.6494 *$ & 0.0750 & $1.8302 * *$ & 0.0290 & 0.9257 & 0.2730 \\
\hline Ddegree & 0.3352 & 0.6120 & $1.5938 * *$ & 0.0260 & 0.8660 & 0.3980 & 0.3987 & 0.5410 \\
\hline Dpostgrad & 0.4324 & 0.6040 & 0.9104 & 0.3660 & -1.4895 & 0.1080 & -0.8012 & 0.4830 \\
\hline DeduOther & -0.3395 & 0.5290 & 0.4652 & 0.4870 & -1.3971 & 0.2900 & 0.0623 & 0.9260 \\
\hline DSingle & -0.8938 & 0.4070 & 0.8701 & 0.2210 & -0.8912 & 0.3710 & 0.5147 & 0.3410 \\
\hline Demployed & 1.5675 & 0.2100 & n.a. & n.a. & n.a. & n.a. & 1.2740 & 0.1050 \\
\hline DEPF & -0.8864 & 0.5390 & $17.133 * * *$ & 0.0000 & $11.8789 * * *$ & 0.0000 & -0.0712 & 0.9310 \\
\hline $\begin{array}{l}\text { Pension \& } \\
\text { others }\end{array}$ & 0.4114 & 0.7650 & $17.576 * * *$ & 0.0000 & $13.4592 * * *$ & 0.0000 & -0.1302 & 0.8820 \\
\hline AGE1 & $0.8311^{*}$ & 0.0540 & $0.9731 * *$ & 0.0250 & 0.8990 & 0.1060 & 0.6652 & 0.1070 \\
\hline _cons & $-9.214 * * *$ & 0.0000 & $-28.65 * * *$ & 0.0000 & $-19.9 * * *$ & 0.0000 & $-5.3380 * *$ & 0.0110 \\
\hline Number of obs & 188 & & 157 & & 157 & & 188 & \\
\hline $\begin{array}{l}\text { Overall fit test } \\
\text { (p-values) }\end{array}$ & 0.0014 & & 0.0000 & & 0.0000 & & 0.0242 & \\
\hline
\end{tabular}


INTERNATIONAL JOURNAL OF ACADEMIC RESEARCH IN BUSINESS AND SOCIAL SCIENCES Vol. 8, No. 7, July 2018, E-ISSN: 2222-6990 @ 2018 HRMARS

Pseudo R-

$\begin{array}{lllll}\text { squared } & 0.3704 & 0.4054 & 0.4932 & 0.4035\end{array}$

Note: $1 .{ }^{* *},{ }^{* *}$, and ${ }^{*}$ represent $1 \%, 5 \%$ and $10 \%$ significant level respectively; 2 . n.a. $=$ not applicable; 3.Repayment in categories of: $1=$ " less than 1 month"; $2=$ "2 to 3 months"; $3=$ "3 to 4 months"; 4 = "more than 4 months"; 4 . Comparison group of dummy variables: Dmale (female); DMalay (Non-Malay); Ddegree, Dpostgrad, DeduOther (Diploma); DSingle (Married); Demployed (employed); DEPF, DPension \& Othr (non-retirement scheme); 5.AGE1 in categories of: $1=$ "less than $20 " ; 2=" 21$ to $29 " ; 3=" 30$ to $39 " ; 4=" 40$ to $49 ; 5=$ " 50 $60 "$ 


\section{References}

1. Alias, N. Z., Huat, Q. B., \& Mohamad, A. A. (2014). Malaysia: Loans and Household Debt-An Assessment. Economic Research, Malaysian Rating Corporation Berhad, 1-12.

2. Antwi, S., Mills, A., Mills, G. A., \& Zhao, X. (2012). Risk Factors of Loan Default Payment in Ghana: A Case Study of Akuapem Rural Bank. International Journal of Academic Research in Accounting, Finance and Management Sciences, 2(4), 376-386.

3. Bank Negara Malaysia, Annual Report, Kuala Lumpur, 2005.

4. Bank Negara Malaysia, Annual Report, Kuala Lumpur, 2013.

5. Beer, C., \& Schurz, M. (2007). Characteristics of Household Debt in Austria: Does Household Debt Pose A Threat to Financial Stability? Monetary Policy and The Economy Q2/07, 58-75.

6. Berger, A. N., \& Molyneux, P. (2015). The Oxford Handbook of Banking. London: Oxford University Press, USA.

7. Bui, U. (2015). Everything You Need to Know About A Home Down Payment retrieved from https://www.nwoc.org/news/everything-you-need-to-know-about-a-home-down-payment

8. Endut, N., \& Hua, T.G. (2009). Household Debt in Malaysia, EconPapers, 46, 107-116.

9. Dodson, C. B., \& Koenig, S. R. (2008). Determining Default Probabilities for FSA Direct Loans. Proceedings: 2008 Agricultural and Rural Finance Markets in Transition, 1-37.

10. Durkin, T.A., \& Elliehausen, G. (2015). Consumer Lending. in Berger, A. N., \& Molyneux, P. (2015). The Oxford Handbook of Banking. London: Oxford University Press, USA.

11. Faruqui, U. (2008). Indebtedness and the Household Financial Health: An Examination of the Canadian Debt Service Ratio Distribution. Working Paper, Bank of Canada, 1-26.

12. Feschijan, D. (2008). Analysis of the Creditworthiness of Bank Loan Applicants. Economics and Organization, 5(3), 273-280.

13. Frais. C. (2017). The Lucas Fox Guide to Buying a Property in Spain. Retrieved from https://www.lucasfox.com/news-and-press/2017/03/14/lucas-fox-guide-buying-property-spain2017/

14. Hamed, M. A., Yaakub, N. I., Mujani, W. K., Sharizam, M., \& Jusoff, K. (2011). Factors Adopting Islamic Home Financing: A Case Study Among Consumers of Islamic Banks in Malaysia. Middle-East Journal of Scientific Research, 7, 47-58.

15. Haron, S., \& Wan Azmi, W. N. (2005). Marketing Strategy of Islamic Banks: A lesson from Malaysia. Proceeding of the International Seminar on Enhancing Competitive Advantage on Islamic Financial Institutions (ECAIFI, 2005), Malaysia.

16. Hui, L. (2011). Household Debt in Malaysia-Is It Sustainable? Penang Economic Monthly, 13(8), 54-58. 17. Jimenez G., \& Saurina J. (2002). Loan Characteristics and Credit Risk. Bank of Spain. DirectorateGeneral of Regulation (2002). Retrieved from https://www.bis.org/bcbs/events/wkshop0303/p03jimesaur.

18. Johnson, K., \& Li, G. (2010). The Debt Payment to Income Ratio as An Indicator of Borrowing Constraints: Evidence from Two Household Surveys. Journal of Money, Credit and Banking, 42(7), 1373-1390.

19. Kamakodi, N. \& Khan, B. A. (2008), An insight into factors influencing bank selection decisions of Indian Customers, Asia-Pacific Business Review, 4(1), 17-26.

20. Kamarulzaman, Y., \& Madun, A. (2013). Marketing Islamic Banking Products: Malaysian Perspective, Business Strategies Series, 14 (2/3), 60-66. 
21. Korankye, A. A., (2014). Causes and Control of Loan Default/Delinquency in Microfinance Institutions in Ghana. American International Journal of Contemporary Research, 4(12), 36-45.

22. Krejcie, R. V., \& Morgan, D. W. (1970). Determining Sample Size for Research Activities. Educational and Psychological Measurement, 30, 607-610.

23. Mahtab, N., \& Abdullah, M. (2016). Marketing of Financial and Banking Products: An Example from Bangladeshi Bank. Journal of Accounting and Marketing, 5(2), Doi:10.4172/2168-9601.1000159.

24. Malay Mail Online (29 April 2016). Retrieved from http://www.themalaymailonline.com/malaysia/article/malaysias-household-debt-to-gdp-stands-at$\underline{89}$

25. McLaughlin, K. (2009). Problem Loan Management: Know the Red Flags and Move Quickly. RMA Journal, 66-68.

26. MIDF Research (2016). High Household Debt in Malaysia is Not A Systemic Risk. Economic Review, 14.

27. Nakornthab, D. (2010). Household Indebtedness and Its Implications for Financial Stability. SEACEN Research and Training Centre, Malaysia, 67-88.

28. Nirmala, L. (2008). Principles of Lending. Ifs School of Finance. Global Professional Publishing, London, United Kingdom.

29. Rani, A. M. S., Nordin, B. S. H., Lau, C. C., Lim, S. L., \& Siow, Z. S. (2017). Rich Debt, Poor Debt: Assessing Household Indebtedness and Debt Repayment Capacity. BIS Paper, No. 9, 153-168.

30. Singh, D. Finance 101: The Whiz Kid's Perfect Credit Guide. The Teen Who Refinance His Mother's House and Car at 14. AuthorHouse, Bloomington; 2012

31. Sorenson, D. J. (2015). Loan Characteristics, Borrower Traits and Home Mortgage Foreclosures: The Case of Sioux Falls, South Dakota. The Journal of Regional Analysis and Policy, 45(2), 163-172.

32. Standard Chartered Report (2016). Retrieved from htts://research.sc.com.

33. The Edge, "Household debt in Malaysia - Is it sustainable?," November, 2010. Retrieved from http://www.consumer.org.com.

34. The Statistics Department of Malaysia, Quarterly Report, 2014-2016.

35. Vanston, N. (2012). Trust and Reputation in Financial Services, Foresight, Government Office for Science, 3-17.

36. Yusof, S.A., Rokis, R.A., \& Jusoh, W.J.W. (2015). Financial Fragility of Urban Households in Malaysia. Jurnal Ekonomi Malaysia, 49(1), 15-24.

37. Zablon, E., Sambiri, M. J., Otieno, O. D. (2015). Evaluation of The Factors Leading to Loan Default at Equity Bank, Kenya. Journal of Economics and Sustainable Development, 6(9), 251-259.

38. Zikmund, W. J., \& Babin, B. J. (2007). Essentials of Marketing Research (5 ${ }^{\text {th }}$ Ed.), South-Western Cenage Learning, USA.

Acknowledgments: We would like to thank Universiti Utara Malaysia for providing financial support for this study through its FRGS-KPT research grant (Code S/O: 12914). 